\title{
Expanding the Influence of Cancer Education
}

\author{
Karen Patricia Williams
}

Published online: 10 June 2010

(C) Springer 2010

A women's health movement is underway across the Atlantic on the continent of Africa. It is unlike the women's health movement born in United States in the 1960s and 1970s where a number of issues were part of the agenda, such as physician-patient relationship, the safety of drugs and devices as well as women's reproductive rights, dominated the agenda [1]. Breast and cervical cancer awareness and prevention and early detection are the catalysts for this movement in Africa. In the last 3 years, the Princess Nikky Breast Cancer Foundation, based in Nigeria, has been holding breast cancer conferences in different countries, first in Nigeria, then Egypt, and most recently, Uganda.

Dedicated to changing the value system within the ministries of health with regard to program funding for women's health, beginning with breast and cervical cancer prevention and early dedication, Princess (her first name and not her title) Nikky Onyeri, used the time-honored strategy of bringing the stakeholders to the table (health educators, researchers, advocates, and policy makers). Of these stakeholders, the policy makers are the key reason that this movement has increasing momentum. These policy makers included the first ladies of various countries, some members (both women and men) of parliaments, and the health ministers.

Working with a first lady to influence her husband is certainly not new. History tells us how African Americans called on first lady Eleanor Roosevelt to use her influence

K. P. Williams $(\bowtie)$

Obstetrics, Gynecology \& Reproductive Biology,

Michigan State University,

East Lansing, MI, USA

e-mail: Karen.Williams@ht.msu.edu to allow African American nurses to actively serve during World War II [2].

At the meeting in Uganda, first lady Janet Kataaha Museveni (also a member of the Parliament) and the Deputy Speaker of Parliament, Rebecca Alitwala Kadaga invited nearly 200 of the stakeholders to a parliament session at the close of the meeting. We witnessed Mrs. Kataaha Museveni address the members issuing a call to action. Other members of parliament who attended the breast cancer conference gave poignant speeches from their own perspectives. This was timely. It was budget time. One parliament member then introduced a motion to set aside $15 \%$ of the health ministry budget for breast and cervical cancer awareness education and to strengthen the cancer screening treatment infrastructure in the country. In Uganda, as in many other African countries represented at the conference, cancer infrastructure is lacking. Cancer centers are rare, and so are registries, and fragmented health systems deliver cancer treatment and awareness and early detection campaigns are nearly nonexistent. Some countries have national cancer control programs as guided by the World Health Organization, but not Uganda. Following this session, members of parliament from other countries informally met with their ministers of health and others in their delegation to strategize their own next steps.

As an invited speaker for the conference of nearly 400 participants and an observer, I was awed. Fate does not always give us a chance to play a role in such a meaningful movement that will impact lives. As our universities look toward the global community to increase student enrollment and influence (also known as academic globalization), those who conduct cancer research and education have an opportunity to expand our influence internationally; to take a lead within our own institutions as it relates to making the world cancer free. 
Being part of such a movement would provide a wonderful opportunity to be engaged in double-loop learning. We would step out of our "expert/professional role" to learn about the actual needs as defined by the people and then understand how our desire to conduct research and or education can appropriately and culturally mesh [3]. This would be a means to develop true partnerships for collaborative cancer research and education. We would be utilizing the same skills that enable us to conduct community-based research and develop university community partnerships [4], in our own environments. If we did this we would be engaged in the dissemination process at the next level as well as expanding our own thinking about interconnectivity. This could give the members of the American Association for Cancer Education and the Cancer Patient Education Network an opportunity to be on the cutting edge of working with people internationally to make a very real difference. Certainly, infrastructure building is not easy work. However, I have found that those who engage in eliminating cancer are among the most passionate about their work! They know they are making a difference.

At the upcoming 2010 AACE/EACE/CPEN Conference, October 25-27, 2010 in San Diego, CA, USA, Dr. Amr
Soliman from the University of Michigan will talk about his university global community partnership. This may be a time to begin gathering more ideas about creative funding and partnerships.

Margaret Mead said, "Never doubt that a small group of thoughtful, committed, citizens can change the world. Indeed, it is the only thing that ever has." Mrs. Tobeka Madiba-Zuma, first lady of South Africa will host the 4th Breast Cancer Conference, March 16 to 17, 2011. Perhaps our group can have a significant presence there. I hope to see you there!

\section{References}

1. Weisman CS (1998) Women's health care: activist traditions and institutional change. The John Hopkins University Press, Baltimore

2. Yellin E (2004) Our mother's war: American women at home and at the front during World War II. Free Press, New York

3. Chambers R (1994) Challenging the professions: frontiers for rural development. Intermediate Technology Publications, London

4. Riger S (2001) Working together: challenges in collaborative research. In: Sullivan M, Kelly JG (eds) Collaborative research: university and community partnership. American Public Health Association, Washington DC, pp 45-60 